\title{
Exchange Rate Management: The Case of Malaysia
}

\author{
YUSUF HAJI OTHMAN, GOH SOO KHOON \\ \& DAWOOD M. MITHANI \\ Faculty of Economics \\ Universiti Utara Malaysia
}

\begin{abstract}
This paper sought to examine whether Purchasing Power Parity (PPP) can become a predictor model for exchange rate. We try to determine whether at least some variant of the PPP-oriented rule may be used in Malaysia as a basis for exchange rate policy. Two methods are used to examine whether longrun PPP holds. The first method is testing whether or not the real exchange rate follows a random walk. The second is the Johansen procedure to test for a long-run relationship between real exchange rate and real economic shocks. It is found that the ringgit real exchange rate follows a random walk, which means PPP does not hold. However, supportive evidence is also seen that there is a long-run relationship between ringgit real exchange rate with current account balance and government spending. The policy implication of this important finding is that some variant of the PPP-oriented rule may be used in Malaysia as a basis for exchange rate policy. Government spending and current account balance can be used as a guide to determine the movement of real exchange rate. The error-correction model shows that real exchange rate, government spending and current account all adjusted to long-run equilibrium. It has a very important policy implication. Fiscal policy, which controls government expenditure, can be used as a tool to manage exchange rate. Measures have to be taken to increase export while at the same time import has to be reduced to maintain the current account balance to be in surplus. This will strengthen the ringgit, thus helping to stabilize the ringgit exchange rate.
\end{abstract}

\begin{abstract}
ABSTRAK
Kajian ini mengkaji sama ada Pariti Kuasa Beli (PPP) boleh dijadikan sebagai model penentu kadar pertukaran. Kami cuba untuk menentukan sama ada sekurang-kurangnya sebahagian varian yang berorientasikan PPP boleh digunakan di Malaysia sebagai asas kepada dasar yang berkaitan kadar pertukaran. Dua kaedah digunakan untuk menentukan sama ada PPP mendapat sokongan empirik. Kaedah pertama ialah menguji sama ada kadar pertukaran benar merupakan suatu siri rawak. Kaedah kedua ialah Kaedah Johansen untuk menguji hubungan jangka panjang antara kadar pertukaran benar dan kejutan ekonomi benar. Kajian ini mendapati bahawa kadar pertukaran ringgit benar merupakan suatu siri rawak, yang bermaksud PPP tidak mendapat sokongan empirik. Walau bagaimanapun, terdapat bukti yang menyokong bahawa wujud hubungan jangka panjang antara kadar pertukaran ringgit benar dengan imbangan akaun semasa dan perbelanjaan kerajaan. Implikasi dasar daripada penemuan penting ini ialah modifikasi yang berasaskan PPP boleh digunakan sebagai asas kepada dasar berkaitan kadar pertukaran di Malaysia. Perbelanjaan kerajaan dan imbangan akaun semasa boleh digunakan sebagai panduan untuk menentukan pergerakan kadar pertukaran. Model pembetulan ralat menunjukkan bahawa kadar pertukaran benar, perbelanjaan kerajaan dan akaun semasa membuat penyelarasan kepada keseimbangan jangka panjang. Ini memberi implikasi dasar yang penting. Dasar fiskal yang mengawal perbelanjaan kerajaan boleh digunakan sebagai alat untuk mengurus kadar pertukaran. Langkah perlu
\end{abstract}


diambil untuk meningkatkan eksport dan pada masa yang sama mengurangkan import supaya akaun semasa berada dalam lebihan. Ini akan mengukuhkan nilai ringgit, dengan demikian membantu untuk mengurus kadar pertukaran menjadi stabil.

\section{INTRODUCTION}

The objective of the present study is to examine whether PPP can become a predictor model for exchange rate-a criteria for judging over valuation and under valuation of RM/USD exchange rate owing to inflation differentials. We try to examine whether at least some variant of the PPPoriented rule may be used in Malaysia as a basis for exchange rate policies in order to determine international competitiveness and to stabilize domestic economy in the short-run. In this paper, an attempt is made to test the hypothesis that the real exchange rate of the ringgit follows a random walk, and the extent on the real shocks that alter the equilibrium relative price between tradable and non-tradable goods, which may be causing deviation from the PPP.

The study is organized as follows. The next section briefly explains the theory of PPP. Section 3 reviews selected literature on Purchasing Power Parity. Section 4 explains the methodology used in this study. Section 5 discusses the results of the study. The last section presents the conclusion of the study.

\section{THE THEORY OF (PPP)}

The PPP theory states that, in the absence of trade barriers and transportation cost, the exchange rate between two currencies is determined by the change in the two countries' relative price levels, in any period of time. The theory, thus, asserts that, in the long run, the only overriding factor affecting the movement in the exchange rate between two currencies is the price level.

According to Cassel (the founder of PPP), if equilibrium is known, then exchange rate should adjust to the change in the relative inflation rate between the two countries (Cassel, 1922, p.175). PPP asserts that movement in exchange rate is determined by movement in the relative purchasing power of money in the two countries, assuming away transportation costs and trade restrictions. In notation:

$$
R=P / P^{*}
$$

where $\mathrm{R}$ is the nominal bilateral exchange rate, measured as units of domestic currency per units of foreign currency, $\mathrm{P}$ is the price level, and the asterisk represents foreign quantity.

PPP is said to be in long run equilibrium if $\mathrm{R}=\mathrm{P} / \mathrm{P}^{*}$. If $\mathrm{R}$ is less than $\mathrm{P} / \mathrm{P}^{*}$, then it is cheaper to buy goods in the foreign country and sell it in the domestic country. This would increase demand for foreign currency relative to domestic currency, which in turn would put upward pressure on the nominal exchange rate until they are at parity, vice versa. In other words, arbitrage activities will ensure that the exchange rate cannot deviate from this equilibrium in the long run. According to Cassel, if equilibrium is known, then exchange rate should adjust to the change in the relative inflation rate between the two countries (Cassel, 1922, p.175).

The theory of PPP is important because if PPP receives empirical support, we can use PPP as a guide to determine our exchange rate. Like Cassel said, if PPP holds, the exchange rate should adjust to the relative inflation rate. In other words, if PPP holds, we can use PPP as a predictor model for our exchange rate.

\section{LITERATURE REVIEW}

The literature on the doctrinal aspect and empirical issues relating to Purchasing Power Parity (PPP) is voluminous. Although PPP has a long history of theoretical support and is one of the most extensively tested hypothesis in openeconomy macroeconomics, empirical evidence 
and tests in favor of the PPP have been weak and inconclusive.

McNown \& Wallace (1989), and Su Zhou, (1997) for instance, investigated the experience of high inflation countries and found evidence supporting the PPP ${ }^{\mathrm{i}}$. Likewise, Abuaf \& Jorion (1990), Kim (1990), Backetti et al, (1995), and Glen, (1992) using relatively long-horizon data, and also Pippenger (1993) using post-Bretton Woods data, observed supportive evidence of PPP. Many others, on the other hand, have rejected the hypothesis that there exists a long run relationship between the exchange rate and price ratio ${ }^{\mathrm{ii}}$.

Studies conducted by Frenkel (1978), Edison (1997), Corbae \& Ouliaris (1988), Taylor (1988), Meese \& Rogoff (1988), Baillie and Patrick (1989), Gan (1991), Flynn \& Boucher (1993), as well as Chowdhury \& Sdogati (1993), suggested that exchange rates in the long run can better be described as a random walk, thus, rejecting the PPP hypothesis. This mixed nature of empirical findings has, time and again, inspired more and more studies to solve the puzzle. Some studies attempted to explain failure of the PPP doctrine by looking at the assumptions behind the theory such as transportation costs, trade barriers, non-tradable goods and real economic shocks that alter the equilibrium relative price between tradable and non-tradable goods such as change in tastes, weather condition, technology, and government policy, and productivity growth differentials between countries. When these stringent assumptions are relaxed, the PPP hypothesis is more likely to receive empirical support. Bahmani (1992), for example, observed that in the case of countries such as Italy, Japan and the United Kingdom, productivity differential between countries is one of the major factors contributing to the deviation of the PPP from equilibrium exchange rate.

Dibooghi (1996), using quarterly data for industrial countries such as Germany, Italy and Japan (US dollar as base currency), found supportive evidence that productivity, government spending and real world oil price accounts for deviations from the PPP. Gan (1991), on the other hand, detected that changes in the relative price of tradable goods and the external terms of the trade cannot explain the long-run swing in the effective exchange rate of ringgit.

\section{METHODOLOGY}

Two methods are used to examine whether longrun PPP holds. The first method is testing whether or not the real exchange rate follow a random walk. The second is multivariate co-integration methodology - Johansen procedure - to test for a long-run relationship between real exchange rate and real economic shocks.

The first method of examining whether long-run PPP holds is to test whether or not the real exchange rate follows a random walk. The real exchange rate is defined as the difference between the nominal exchange rate and the relative price levels.

$r_{t}=e_{t}-P_{t}$

where $r_{t}$ is the real exchange rate of the domestic currency against one unit foreign currency and $e_{t}$ and $\mathrm{P}_{\mathrm{t}}$ are as defined before. If the real exchange rate follows a random walk (in time series jargon, this means real exchange rate is non-stationary), then there will be no tendency for the nominal exchange rate and the relative price levels to converge even in the long run. This implies that the PPP will not hold.

The price level is usually represented by the wholesale price index (WPI), the consumer price index (CPI) or GDP deflator. The use of WPI is usually favored as a measure of the PPP because conceptually, WPI is heavily weighted with tradable goods compared to CPI, which covers both tradable and non-tradable goods sectors. However, as noted by Officer (1978), CPI has the advantage of being a base-weighted index designed to measure change in the price level of an average basket of commodities of an economy. In our study, both WPI and CPI are used since only these two types of price indices are available in quarterly form in Malaysia ${ }^{\mathrm{iii}}$. Besides, we would like to test whether the choice of the price index matters by considering both price indices in the PPP analysis.

The second method is multivariate co-integration methodology - the Johansen procedure - to test for a long-run relationship between real exchange rate and real economic shocks. 
In this study, we test whether the real disturbance outlined above has caused deviation from the PPP. This is done by augmenting the PPP with differential government spending on non-tradable goods and current account imbalance in Malaysia. In this regard, we specifically consider the following equation:

$r_{t}=\beta_{o}+\beta_{1}\left(g_{t}-g_{t} *\right)+\beta_{2} C A_{t}+\mu_{t}$

where $r_{t}$ is the logarithm of the CPI or WPI real exchange rate ringgit with the US dollar, $g_{t}, g_{t}$ * are the nominal Malaysia and US government spending on non-tradable goods and $\mathrm{CA}_{t}$ is the current account balance in Malaysia.

Since it is not possible to decompose government expenditure into spending on tradable vs. non-tradable, we used general government expenditure in national account as a proxy for the government spending on non-tradable goods.

The quarterly data on CA balance are not available in Malaysia; we used trade balances as a proxy for CA balance. Current account records transactions of goods, services and transfer payment. If export is greater than import, current account is in surplus. On the other hand, if import is greater than export, current account is in deficit. Therefore, we use trade balance (export - import) as a proxy for current account.

Two models have been tested in this context. Model 1 is based on the CPI real exchange rate which begins from 1973:1 to 1997:2. Model 2 is based on the WPI real exchange rate, for which the data begins from 1984:1 onwards.

All the data are taken from IMF's International Financial Statistics, CD-ROM. The quarterly sample period for the CPI real exchange rate is from 1978.1 to 1997.2 , while the sample period for the WPI real exchange rate is from 1984.1 to 1997.2.

\section{EMPIRICAL RESULTS}

In our analysis of empirical results, we begin with univariate unit root tests for the two variants of real exchange rate of the ringgit: CPI-based and WPI-based real exchange rates. Figure 1 and 2 plot both series. Inspection of both figures indicate that through times the ringgit experienced a real depreciation with no tendency to revert to a long-run mean.

\section{RRCPI}

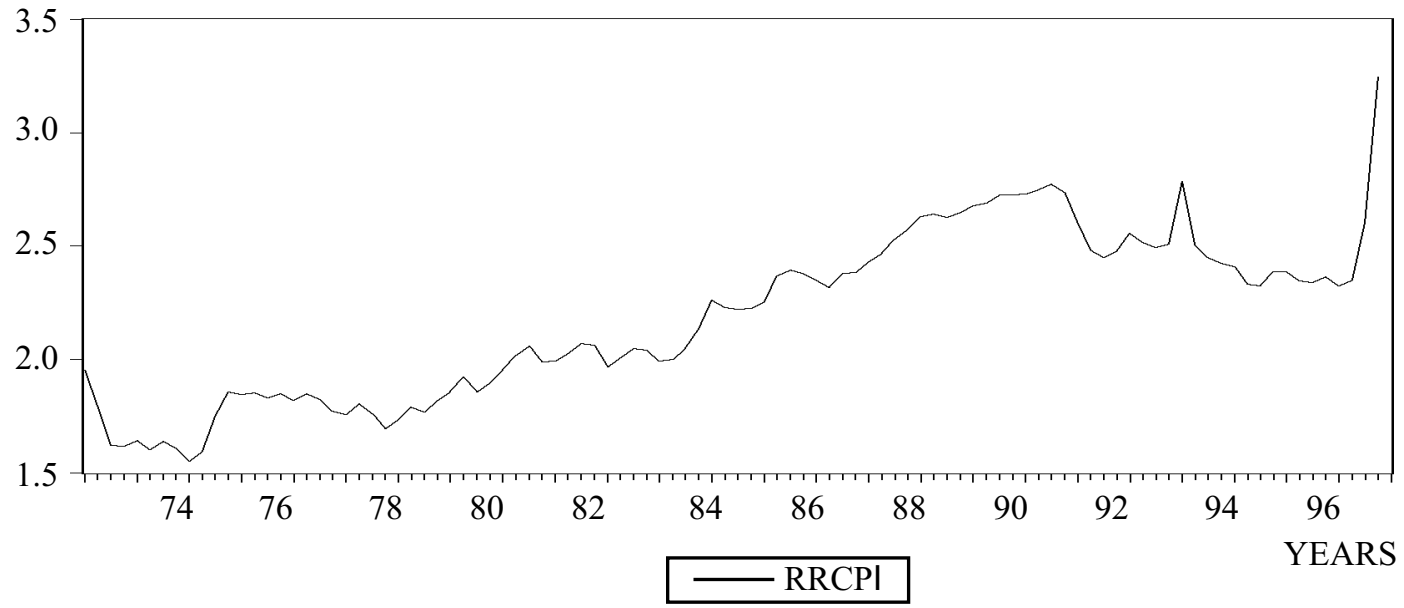

Figure 1

CPI Based Real Exchange Rate (RRCPI) 


\section{RRWPI}

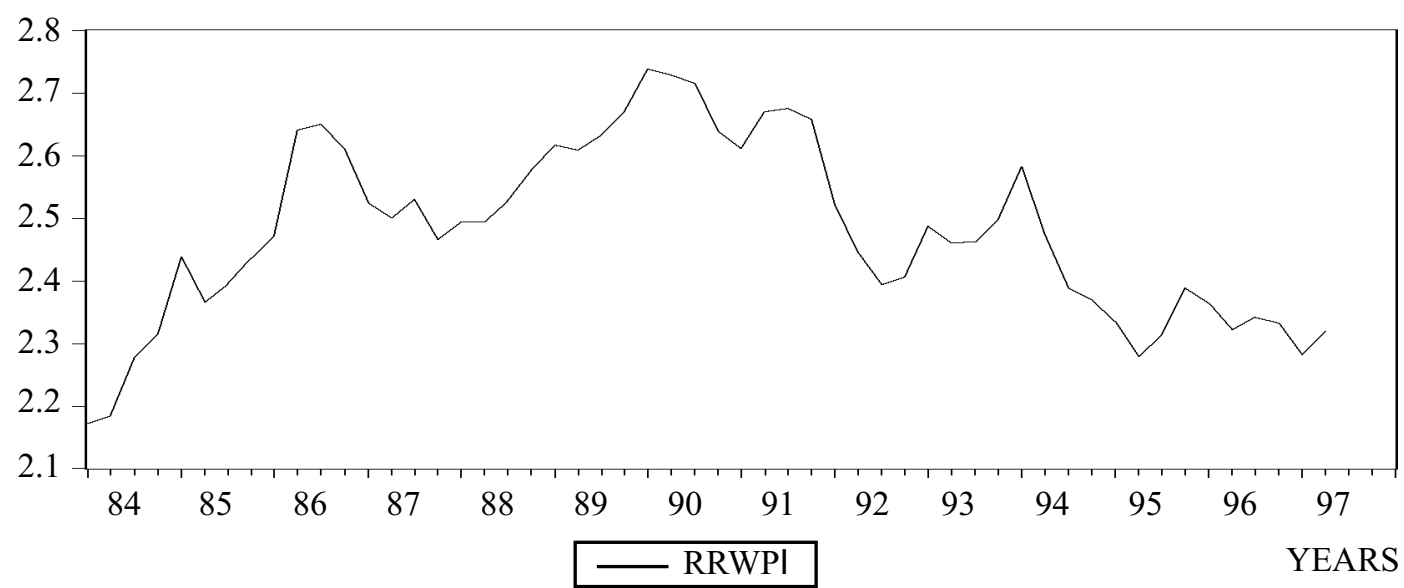

Figure 2

WPI Based Real Exchange Rate (RRWPI)

We ran an $\mathrm{ADF}$ unit root test on both $\mathrm{CPI}$ and WPI-based real exchange rates. The ADF test involved regressing the first difference of a variable on a constant, its lagged level and $\mathrm{k}$ lagged first differences.

$$
\underset{\mathrm{i}}{\Delta \mathrm{r}_{\mathrm{t}}=\beta_{\mathrm{i}} \mathrm{\beta o}+\beta_{\mathrm{t}-1} \mathrm{r}_{\mathrm{i}}+\sum \gamma_{\mathrm{j}} \Delta_{\mathrm{r}-\mathrm{i}}+\varepsilon_{\mathrm{t}}}
$$

Table 1

Unit Root Test Results
We started with $\mathrm{k}=4$ (since the data was quarterly) and insignificant lag were deleted to whiten the residuals based on Box-Pierce Q-test. The white noise errors were necessary to get valid tstatistics. The $\mathrm{ADF}$ equations for the test on the real exchange rate included time-trend term, to allow for a deterministic trend in the series. The result are reported in Table 1. The critical values for the t-statistics of the ADF equations were based on MacKinnon (1991).

\begin{tabular}{|l|c|c|}
\hline Variable & t-statistic/ () & $\mathrm{Q}(20) /$ prob \\
\hline $\begin{array}{l}\mathrm{r}(\mathrm{T}) \\
\text { (CPI based) }\end{array}$ & $-2.64(1)$ & $10.98(0.95)$ \\
\hline $\mathrm{r}(\mathrm{T})$ & $-2.31(0)$ & $8.6226(0.98)$ \\
(PPI based) & & \\
\hline
\end{tabular}

Note: (T) means a constant with a time trend included.

(P) means the chosen lag length are included in each series.

$\mathrm{Q}(20)$ refers to the Q-statistics with 20 degrees of freedom. Prob refers to the probability level at that degree of freedom. The $5 \%$ critical value of Q (20) is 31.41 .

The MacKinnon (1991) t-critical values for the sample size of 50 are 1\%-4.15, 5\%-3.50, 10\%-3.18

100 are $1 \%-4.04,5 \%-3.45,10 \%-3.15$ 
The results of the unit root tests reported in Table 1 indicate that the null hypothesis of a random walk for the real exchange rate cannot be rejected for either the CPI-based real exchange rate series or the WPI real exchange rate series.
Besides that, we also look at the autocorrelation functions of the CPI-based and WPIbased real exchange rate series. Correlogram of both series shows that the Q-Stat of both series is significant at 36 lags, which is very high. Table 2 reports the Q-Stat and Prob of selected lags for both series.

Table 2

Q-Stat of Autocorrelation Functions for CPI- based (RRCPI) and WPI-based (RRWPI) Real Exchange Rate

\begin{tabular}{|l|lllll|}
\hline Variable & Lag & ACF & PACF & Q-Stat & Prob \\
\hline & 1 & $0.698 / 0.861$ & $0.698 / 0.861$ & $28.775 / 42.314$ & $0.000 / 0.000$ \\
\cline { 2 - 6 } & 2 & $0.526 / 0.686$ & $0.076 /-0.214$ & $45.434 / 69.708$ & $0.000 / 0.000$ \\
\cline { 2 - 6 } & 3 & $0.440 / 0.550$ & $0.092 / 0.068$ & $57.279 / 87.653$ & $0.000 / 0.000$ \\
\cline { 2 - 6 } RRCPI/RRWPI & 35 & $0.016 /-0.082$ & $-0.037 /-0.056$ & $179.90 / 337.50$ & $0.000 / 0.000$ \\
\cline { 2 - 6 } & 36 & $0.010 /-0.075$ & $-0.057 / 0.071$ & $179.92 / 338.44$ & $0.000 / 0.000$ \\
\hline
\end{tabular}

Note: Numbers to the left of / belong to RRCPI while numbers to the right of / belong to RRWPI

Table 2 shows that the Q-Stat of both series are significant for lags 1 through 36 . This indicates that both series are non-stationary. Therefore, we show that both series are nonstationary using both the Augmented Dickey-Fuller Test (ADF) and the Autocorrelation Function (ACF).

These findings are consistent with the work of other researchers such as Gan's (1991) who found a unit root in the Ringgit's real effective exchange rate. There are two possible reasons as to why one may fail to reject the null hypothesis of the non-stationarity for the real exchange rate. Firstly, as has been pointed out by Edison et al., (1997) the small sample size of data have very low power to reject the random walk model of real exchange rate. They pointed out if the PPP deviations damp sufficiently slowly, then it must require many decades of data for one to be able to reject the existence of a unit root in real exchange rate. Therefore, one must look to a longer data set. The second possible reason is that there are some real disturbances that caused deviations from the PPP in Malaysia. Since we are constrained by the small data size, our focus is on identifying real disturbances that caused deviations from the PPP.

After we found that the real exchange rate followed a random walk which means the PPP does not hold in the case of Malaysia, we made an attempt to determine whether the non-stationary deviations from the PPP can be explained by real disturbance in certain market "fundamentals" that determine the long-run equilibrium exchange rate. Non-stationary change in the real exchange rate can arise due to real disturbance that changes the equilibrium relative price between tradable and non-tradable goods. If the observed deviations from the PPP are due to changes in these equilibrium relative prices, then it can be expected that the ringgit real exchange rate is co-integrated with these economic fundamentals.

Permanent change in the real exchange rate can arise due to real disturbance that change equilibrium relative price between tradable and nontradable goods. The Samuelson-Balassa hypoth- 
esis identified productivity differentials between tradable and non-tradable as the determinants of relative price between tradable and non-tradable (Samuelson, 1964 \& Balassa, 1964). There has also been a considerable amount of progress in recent years in analyzing the effect of government spending shock on real exchange rate. Froot \& Rogoff (1991) sought to find out to what extent the increase in government spending explains the significant shift in real exchange rate over the EMS period. They regressed the real CPI exchange rate against various measures of productivity differentials and government spending. The government spending variable consistently enters with the correct sign in all the individual country regressions and is strongly significant in the pooled time-series cross-section regression. They argued that it is because government spending leads to an increase in the real exchange rate.

Another important consideration to the determination of the PPP in long run is the current account imbalances. Theoretically, substantial current account (CA) deficits are associated with long-run real exchange rate depreciation. Hooper \& Morton, (1982) empirically found a strong correlation between CA deficits and exchange rate depreciation over a five to ten year horizon. The possible correlation between these two variables are also supported by Krugman (1990). He argues that CA deficits are likely to induce significant exchange rate changes because different countries tend to exhibit different spending patterns.

In Malaysia, the current account deficit problem was considered to be of a grave nature only in the 1980 s on account of the world recessionary impact. In 1982, the CA deficit was about $14 \%$ of the total GNP. The rapid recovery after the year 1985 substantially improved the CA balance in the country. However with the rapid growth at the beginning of the 1990s, an investment boom without an increase in the domestic saving rate lead to a high CA deficit again since 1993. The CA deficit with a slow moving of foreign capital inflows has a negative implication on the exchange rate of the ringgit.

The other important determinant of the relative prices of non-tradable goods in Malaysia has been the rapid growth in government expenditure in the 1980s. Government expenditure as a percentage of the GDP rose from an average of 17 per cent in the late 1950s to a peak of 37 per cent in the early 1980s. In both recessionary times (1983-85, 1998), we found the Malaysian government to be adopting the Keynesian remedy, i.e. increasing the government spending in order to boost the economy.

A precondition for the cointegration test is whether the individual series on rt, CAt, and (gt-gt*) has a common order of integration. Based on the ADF test, Table 3 presents evidence that each series is integrated by order one; that is, each series is 1(1). The ADF test on (gt-gt*) series includes an intercept and time-trend term. In testing for unit root in the first difference, only the intercept is included in all series. Each test equation includes 4 lags, where the adequacy of the lag length (indicated in Table 3 ) is checked with tests for serial correlation using the Box-Pierce Q-test.

Table 3

Unit Root Test Result.

\begin{tabular}{|l|l|l|}
\hline Variable & t-statistics/ (p) & Q (20)/prob \\
\hline $\begin{array}{l}\text { Model 1(CPI based real } \\
\text { exchange rate, 1973.1- } \\
1997.2)\end{array}$ & & \\
\hline$\left(\right.$ gt-gt*)(T) $^{\text {(T) }}$ & $-2.32(1,2,3,4)$ & $25.13(0.19)$ \\
\hline
\end{tabular}


(continued)

\begin{tabular}{|c|c|c|}
\hline Variable & t-statistics/ (p) & Q (20)/prob \\
\hline $\mathrm{CA}(\mathrm{C})$ & $-2.87(7,8)$ & $17.69(0.61)$ \\
\hline $\begin{array}{l}\Delta \mathrm{r}(\mathrm{C}) \\
\text { CPI based }\end{array}$ & $-8.10(0)^{* * *}$ & $18.39(0.86)$ \\
\hline$\Delta\left(\mathrm{gt}^{-g t^{*}}\right)(\mathrm{C})$ & $-17.10(1,3,4)^{* * *}$ & $23.82(0.25)$ \\
\hline$\Delta \mathrm{CA}(\mathrm{C})$ & $-6.71(1,7)^{* * *}$ & $19.33(0.50)$ \\
\hline \multicolumn{3}{|c|}{$\begin{array}{l}\text { Model } 2 \text { (WPI based real } \\
\text { exchange rate, 1984.1- } \\
\text { 1997.2) }\end{array}$} \\
\hline$\left(g t-g t^{*}\right)(T)$ & $-2.84(1,2,3)$ & $24.80(0.21)$ \\
\hline $\mathrm{CA}(\mathrm{C})$ & $-2.15(0)$ & $10.12(0.92)$ \\
\hline $\begin{array}{l}\Delta \mathrm{r}(\mathrm{C}) \\
\text { WPI based }\end{array}$ & $-6.23(0)^{* * *}$ & $7.02(0.97)$ \\
\hline$\Delta\left(\mathrm{gt}^{-g t^{*}}\right)(\mathrm{C})$ & $-26.22(1,2)^{* * *}$ & $22.36(0.32)$ \\
\hline$\Delta \mathrm{CA}(\mathrm{C})$ & $-5.91(0)^{* * *}$ & $12.05(0.91)$ \\
\hline
\end{tabular}

Note: ${ }^{* * *}$ significant at $1 \%$

(c) means a constant is included

(T) means a constant and a time trend are included

(P) means the significance lags are included in each series

$\mathrm{Q}$ (20) refers to the Q-statistics with 20 degrees of freedom. Prob refer to the probability level at that degree of freedom. The $5 \%$ critical value of Q (20) is 31.41 .

The Mackinnon (1991) t-critical values for the size sample of 100

(T) are: $1 \%-4.04,5 \%-3.45,10 \%-3.15$

(C) are: $1 \%-3.51,5 \%-2.89,10 \%-2.58$

The MacKinnon (1991) t-critical values for the size sample of 50

(T) are: $1 \%-4.15,5 \%-3.50,10 \%-3.18$

(C) are: $1 \%-3.58,5 \%-2.93,10 \%-2.60$

Cointegration is tested using Johansen's (1988) maximum likelihood procedure based on the vector error-correction model of the following form:

$\Delta \mathrm{Y}_{\mathrm{t}}=\sum_{\mathrm{i}=1} \alpha_{\mathrm{i}} \Delta_{\mathrm{t}-\mathrm{i}+1}^{\rho-1}+\Pi \mathrm{Y}_{\mathrm{t}-1}+\varepsilon_{\mathrm{t}}$ where $Y_{t}$ is the $3 \times 1$ vector of all are I (1) process $r_{t}, C A_{t},\left(g_{t}-g_{t}^{*}\right) . Y_{t-1}$ is the $3 x 1$ vector that contains the first lag of the variables $r_{t}, C A\left(g_{t}-g_{t}{ }^{*}\right)$. The long run relationship in the data set is captured in the $\Pi$ matrix. If the rank of $\Pi$ is $w$, then there is $w$ linear combination of the variables in the system that is cointegrated. The $\Pi$ can be decomposed 
into two $\mathrm{n} x \mathrm{r}$ matrices $\alpha$ and $\beta$ such that $\Pi=\alpha \beta$ '. The matrix $\beta$ contains the coefficients of the matrix of cointegrating parameters, and the matrix $\alpha$ is the matrix of the speed of adjustment coefficient in each equation. The $\varepsilon_{t}$ is a vector of the white noise process.

The Johansen technique has several advantages over the Engle \& Granger (1987) test. Firstly, the Johansen technique explicitly tests for the number of cointegrating vectors. Secondly, it treats all the variables as endogenous, thereby avoiding an arbitrary choice of the dependent variable as in the Engle-Granger test. The parameter estimates are thus much more efficient and are a more powerful test than the Engel-Granger test.

To run the Johansen test, we should first test the appropriate lag length since the result of the Johansen test can be quite sensitive to the number of lag length. The Sim's likelihood ratio tests were performed ${ }^{\text {iv }}$.

Taking into account that the data are quarterly, Vector Auto Regression (VAR) models with 8,6,4 and 2 are specified for the CPI based real exchange rate model $(6,4$ and 2 lags for WPI based real exchange rate model), with common lags for all three variables in each model. The computed likelihood ratio statistics follows a chi-square distribution, with a degree of freedom equal to the number of variables omitted in the restricted model. The null hypothesis that all omitted lags in the restricted model have zero coefficients, was tested for lags from 8 to 6,6 to 4 and 4 to 2 . The result of the test is presented in Table 4 .

\section{Table 4}

\section{Likelihood Ratio Test}

$\mathrm{H}_{0}$ : All omitted lags in the restricted model have zero coefficients

\begin{tabular}{|c|c|c|}
\hline Lags & $\chi^{2}$ statistics & Conclusion \\
\hline \multicolumn{3}{|c|}{ Model 1 (CPI based real exchange rate) } \\
\hline 4 to 2 lags & 157.28 & Reject $\mathrm{H}_{0}$ at $1 \%$ level of significance \\
\hline 6 to 4 lags & 14.10 & $\begin{array}{l}\text { do not, reject } \mathrm{H}_{0} \text { at } 1 \% \text { level of } \\
\text { significance }\end{array}$ \\
\hline 8 to 4 lags & 43.09 & $\begin{array}{l}\text { do not reject } \mathrm{H}_{0} \text { at } 1 \% \text { level } \\
\text { of significance }\end{array}$ \\
\hline \multicolumn{3}{|c|}{$\begin{array}{l}\text { The degree of freedom for the lags from } 4 \text { to } 2 \text { and } 6 \text { to } 4 \text { are } 18 \text {, from } 8 \text { to } 4 \text { are } 36 \\
\text { The } \chi \text { critical value for degree of freedom } 18 \text { are: } 1 \% 34.80,5 \% 8.87,10 \% 25.98 \\
36 \text { are: } 1 \% 63.69,5 \% 55.75,10 \% 51.80\end{array}$} \\
\hline \multicolumn{3}{|c|}{ Model 2 (WPI based real exchange rate) } \\
\hline 4 to 2 lags & 79.37 & Reject Ho at $1 \%$ level of significance \\
\hline 6 to 4 lags & 26.69 & $\begin{array}{l}\text { do not reject Ho at } 1 \% \text { level } \\
\text { of significance }\end{array}$ \\
\hline
\end{tabular}


In model 1 , the $\chi^{2}$ test statistics for lags from 4 to 2 is bigger than the critical value at the $1 \%$ level of significance, therefore, the null hypothesis is rejected. This implies that the lags from 4 to 2 are statistically significant. The $\chi^{2}$ test statistics for the lags 6 to 48 to 4 are smaller than the critical value at the $1 \%$ level of significance, therefore, we fail to reject the null hypothesis.
This means that the best lag length for the CPI based real exchange rate model is 4 lags. In model 2, we also found that the 4 lags specification was to be the best for the WPI based real exchange rate model. Thus, we used specific 4 lags for both models in the Johansen test. The results of the Johansen test are shown in Table 5.

Table 5

Johansen Cointegration Test.

\begin{tabular}{|l|l|l|l|c|c|c|}
\hline $\begin{array}{l}\text { Model 1(CPI based } \\
\text { real exchange rate) }\end{array}$ & \multicolumn{4}{|l|}{$\lambda$ max } \\
\hline $\begin{array}{l}\text { Null Hypothesis } \\
\left(\mathrm{H}_{0}\right)\end{array}$ & $\mathrm{r}=0$ & $\mathrm{r}=1$ & $\mathrm{r}=2$ & $\mathrm{r}=0$ & $\mathrm{r} \leq 1$ & $\mathrm{r} \leq 2$ \\
\hline $\begin{array}{l}\text { Alternative } \\
\text { Hypothesis (H) }\end{array}$ & $\mathrm{r}=1$ & $\mathrm{r}=2$ & $\mathrm{r}=3$ & $\mathrm{r}>0$ & $\mathrm{r} \geq 2$ & $\mathrm{r} \geq 3$ \\
\hline $\begin{array}{l}\text { Model 2 (WPI based } \\
\text { real exchange rate) }\end{array}$ & 10.31 & 5.73 & 0.90 & 16.94 & 6.63 & 0.90 \\
\hline $\begin{array}{l}\text { Null Hypothesis } \\
\text { (Ho })\end{array}$ & $\mathrm{r}=0$ & $\mathrm{r}=1$ & $\mathrm{r}=2$ & $\mathrm{r}=0$ & $\mathrm{r} \leq 1$ & $\mathrm{r} \leq 2$ \\
\hline $\begin{array}{l}\text { Alternative } \\
\text { Hypothesis (H_) }\end{array}$ & $\mathrm{r}=1$ & $\mathrm{r}=2$ & $\mathrm{r}=3$ & $\mathrm{r}>0$ & $\mathrm{r} \geq 2$ & $\mathrm{r} \geq 3$ \\
\hline & $22.20^{*}$ & 9.88 & 3.36 & $35.45^{*}$ & 13.25 & 3.36 \\
\hline
\end{tabular}

Note: The second column reports the $\lambda$ max statistics as the number of observations multiplier in (1-^ $\lambda 1)$ where $\wedge \lambda 1$ is the estimated value of the characteristic roots or eigenvalues obtained from the estimated $\pi$ matrix. The last column reports the $\lambda$ trace statistics as the summations of $\lambda$ max statistics. $*$ denotes significance at $5 \%$. The critical values for the $\lambda$ max at the $5 \%$ significance level are $21.694(\mathrm{n}-\mathrm{r}=3), 15.75(\mathrm{n}-\mathrm{r}=2)$ and $9.094(\mathrm{n}-\mathrm{r}=1)$. The critical values for the $\lambda$ trace at the $5 \%$ significance level are $35.068(n-r=3), 20.168(n-r=2)$ and $9.094(n-r=1)$ where $n$ denotes the number the of variable in the model and $r$ denotes the number of cointegrating vectors.

The econometric software that we used, EViews, allows us to use different model options to test the Johansen procedure for cointegration. For instance, option B selects a model that does not include a deterministic trend in the data and an intercept but with no trend in the cointegrating equation. Option $\mathrm{C}$ selects a model that includes a linear trend in the data and an intercept but with no trend in the cointegrating equation. We selected option C for both models in the Johansen test since 
the plot of data, $\left(g_{t}-g_{t} *\right)$, showed a clear deterministic trend in the data and the trend was significant in the ADF test. The results shown in Table 4 are fairly interesting. Using CPI as the based real exchange rate, the $\lambda$ max shows that we failed to reject the null hypothesis at the $5 \%$ significance level (but not at the $1 \%$ significance level) at $r=1$ but not $r=2$, concluding that there is only one cointegrating vector in model 2 . Using the $\lambda$ trace statistics, we also arrived at the same result.

We used a shorter time period for the WPI based model than for the CPI based model. However, we found the cointegration result favorable to the WPI based model rather than to the CPI based model. This again certifies that the CPI index which gives a significant weight to non-tradable goods is not a proper measure for the PPP, at least, in the case of Malaysia.

The $\lambda$ max and the $\lambda$ trace statistics indicate a single cointegrating vector for model 2 . Normalizing with respect to the real exchange rate:

$\mathrm{r}_{\mathrm{t}}=-\underset{(3.09)}{-2.855\left(\mathrm{~g}_{\mathrm{t}}-\mathrm{g}_{\mathrm{t}} *\right)}-1.864 C \mathrm{CA}_{\mathrm{t}}-8.939$

(3.09)

where numbers in parentheses indicate the standard error of the parameter. Equation 5 implies that an increase in government spending on home goods is associated with an appreciation of domestic currency. On the other hand, an improvement in the CA balances is associated with an appreciation of the domestic currency.

Cointegration is a necessary and sufficient condition for the representation of the series in an error correction model (ECM) which combines both the short-run dynamics and the long-run equilibrium relations among the series. The Short-run dynamics in the ECM are captured by the Error Correction Term (ECT) and the conventional tests of causality based on the significance of the ECT and any significance of the lagged different terms in the ECM. Since we found one cointegrating vector in model 2-WPI based real exchange rate, it will allow us to proceed with the ECM to identify the causality among variables in the model. Table 6 reports the OLS regression estimates of WPI based $\mathrm{r}, \mathrm{CA}$ and $\left(\mathrm{g}_{\mathrm{t}-\mathrm{g}_{\mathrm{t}}}{ }^{*}\right)$ of the ECM in a restricted form- allowing lags one through four on the differences of all variables- and then omitting insignificant terms. These restricted ECM estimates pass a series of diagnostic test-BoxPierce Q test.

Table 6

OLS Estimates for the ECM

\begin{tabular}{|l|l|l|l|}
\hline Dependent & $\Delta \mathrm{r}$ & $\Delta \mathrm{CA}$ & $\Delta$ (gt-gt*) \\
\hline $\mathrm{C}$ & $0.138(2.08)$ & $-6.012(3.78)$ & $-1.333(2.59)$ \\
\hline $\mathrm{R}(-1)$ & $0.007(2.01)$ & $-0.333(3.74)$ & $-0.075(2.61)$ \\
\hline$\Delta \mathrm{CA}(-3)$ & & $0.481(2.02)$ & \\
\hline$\Delta\left(\right.$ gt-gt*$\left.^{*}\right)(-1)$ & & $0.993(3.84)$ & $-0.800(9.59)$ \\
\hline$\Delta\left(\right.$ gt-g**)(-2) $^{*}$ gt-gt*) $^{2}$ & & $0.422(2.01)$ & $-0.822(10.02)$ \\
\hline $\mathrm{R}^{2}$ & 0.055 & & $-0.866(14.80)$ \\
\hline $\mathrm{Q}(4) /$ prob & $1.30(0.861)$ & 0.244 & 0.918 \\
\hline $\mathrm{Q}(8) /$ prob & $3.34(0.911)$ & $3.5261(0.897)$ & $3.296(0.510)$ \\
\hline $\mathrm{Q}(12) /$ prob & $10.442(0.577)$ & $4.0449(0.983)$ & $7.324(0.502)$ \\
\hline $\mathrm{Q}(20) /$ prob & $14.52(0.803)$ & $7.5791(0.994)$ & $14.922(0.246)$ \\
\hline
\end{tabular}

Note: $\mathrm{R}$ is the residual series from the OLS cointegrating regressions in equation $6 .{ }^{2} \mathrm{R}$ is the adjusted $\mathrm{R}$ - squared. $\mathrm{Q}(\mathrm{n}) /$ prob is the Box-Pierce Q-Statistics at an $\mathrm{n}$ degree of freedom and prob is the level of probability. The numbers in parentheses are the absolute values of t-ratios. 
The major findings reported in Table 6 show that all the ECT are statistically significant. This implies that r, (gt-gt*) and CA all adjusted to long-run equilibrium with the $\mathrm{CA}$ having adjusted the most with a coefficient of 0.33 . It means that $33 \%$ of the disequilibrium in the CA will be corrected in the next period. Indeed, the real exchange rate is adjusted with the least with a coefficient of 0.007 . This may be attributed to the relative low level of inflation in both Malaysia and the US and a managed exchange rate system, which the Central Bank in Malaysia before the currency crisis in 1997, managed the exchange rate to fluctuate within a band of $2.50-2.70$. The significant lagged difference in the ECM implied the causality among variables.

\section{SUMMARY AND CONCLUSION}

The study suggests that the ringgit's real exchange rate follows a random walk. It also identified that the type of price index does matter in the test of the PPP in Malaysia. The WPI index is more favorable than the CPI index. This means the PPP does not receive empirical evidence in the case of Malaysia. Therefore, the PPP cannot be used as a guide to determine the exchange rate in the case of Malaysia. We cannot manage the exchange rate based on the PPP.

However, real shocks to the Malaysian economy often change the relative prices between tradable and non-tradable goods as well as the exchange rate leading to short-term deviation from the PPP. Using Johansen's cointegration methods and quarterly data, the study provides supportive evidence to the hypothesis that government spending and current account balance do account for deviating from the PPP.

This empirical finding is consistent with Melvin (1997)'s proposition that only when there is a large magnitude of increase in the domestic general price level and a longer time frame, then only will there be less important effects of the random relative price between tradable and non-tradable goods changes on the exchange rate. In view of the low inflation rate in Malaysia and in the
US, as well as the short time period that we used, one need not be surprised to see that these relative price effects between tradable and non-tradable goods has dominated the changes on the real exchange rate of the ringgit.

We found that the real exchange rate is cointegrated with government spending and current account balance. It means that these variables have a long-run relationship. In other words, even if in the short-run, these three variables drift apart from each other, but in the long-run these variables will tend to move together over time.

The policy implication of this important finding is that some variant of the PPP-oriented rule may be used in Malaysia as a basis for exchange rate policy. Government spending and current account balance can be used as a guide to determine the movement of real exchange rate.

In addition, the error-correction model shows that real exchange rate, government spending and current account all adjusted to long-run equilibrium. This finding means that, government spending and current account cause the movement in real exchange rate. It has a very important policy implication. Fiscal policy, which controls government expenditure, can be used as a tool to manage exchange rate. In addition, our government has to control current accounts to stabilize the exchange rate. Export has to be increased while at the same time import has to be reduced to maintain the current account balance to be in surplus. This will, in turn, strengthen the ringgit thus helping to maintain our exchange rate.

Currently, our exchange rate is fixed at RM3.80/USD. If one day our government decides to let the exchange rate float, then fiscal policy together with policy that encourages export and discourages import, can be used as a tool to strengthen out ringgit, thus managing to stabilize our exchange rate.

\section{ENDNOTES}

i It is argued that for countries with a high rate of inflation, monetary factors rather than real factors, 
would be expected to dominate exchange rate change.

ii For a comprehensive survey of empirical studies in the PPP literature, see Giovanneti (1992) and Rogoff (1996).

iii The WPI is officially referred to as Producer Price Index (PPI) in US and Malaysia for all practical purposes.

iv The likelihood ratio test estimated by Sims is the following:

$$
\begin{aligned}
& \mathrm{LR}=(\mathrm{T}-\mathrm{c})\left(\operatorname{In}\left|\sum \mathrm{r}\right|-\operatorname{In}\left|\sum \mathrm{u}\right|\right) \sim \chi^{2} \\
& \text { Where }: \mathrm{T}= \text { number of observations in } \\
& \text { the unrestricted model } \\
& \mathrm{c}= \text { number of parameters used } \\
& \text { in the unrestricted model } \\
& \operatorname{In}\left|\sum \mathrm{r}\right|= \text { natural logarithm of the } \\
& \text { determinant of the restricted } \\
& \text { model and } \\
& \operatorname{In}\left|\sum \mathrm{u}\right|= \text { natural logarithm of } \\
& \text { determinant of the } \\
& \text { unrestricted model }
\end{aligned}
$$

\section{REFERENCES}

Abuaf, N. \& Jorion, P. (1990). Purchasing Power Parity in the long run. Journal of Finance, 45, 57-174.

Balassa, B. (1964). The Purchasing Power Parity doctrine: a reappraisal. Journal of Political Economy, 584-96.

Baillie, R. \& Patrick, M. (1989). The foreign exchange market: Theory and econometric evidence. Cambridge : Cambridge University Press.

Bahmani, M. (1992). A time series approach to test the productivity bias hypothesis in Purchasing Power Parity. Kyklos, 45, 227-237.

Becketti, H., Hakkio, C.S. \& Joines, D.H. (1995). Exchange rates in the long run. Federal reserve bank of Kansas City, Working Paper (95-114).
Cassel, G. (1922). Money and Foreign Exchange After 1914. London : Constable.

Chowdhury, A.R. \& Sdogati, E. (1993). Purchasing Power Parity in the major EMS countries: the role of price and exchange rate adjustment, Journal of Macroeconomics, 15, 2545.

Corbae, D. \& Ouliaris, S. (1988). Cointegration and tests of Purchasing Power Parity. Review of Economics and Statistics, 70, 508-611.

Dibooghi, S. (1996). Real disturbances, relative prices and Purchasing Power Parity. Journal of Macroeconomics, 19, 69-87.

Edison, H.J., Gagnon, J.E. \& Melick, W.R. (1997). Understanding the empirical literature on Purchasing Power Parity: the Post-Bretton Woods Era. Journal of International Money and Finance, 16, 1-17.

(1987). Purchasing Power Parity in the long run: a test of the dollar/pound exchange rate (1890-1978). Journal of Money, Credit and Banking, 376-87.

Engle, R. \& Granger, C.W.J. (1987). Cointegration and error correction: representation, estimation and testing. Econometrica, 55, 251-76.

Flynn, N.A. \& Boucher, J.L. (1993). Test of longrun Purchasing Power Parity using alternative methodologies. Journal of Macroeconomics, 15, 109-22.

Frenkel, J. (1978), 'Purchasing Power Parity: Doctrinal Perspective and Evidence from the 1920s.' Journal of International Economics 8, 169-191.

Froot, K. \& Rogoff, K. (1991). The EMS, the $E M U$, and the transition of common currency. National Bureau of Economic Research Macroeconomics Annual. Eds. Stanley Fischer \& Oliver Blanchard. Cambridge: MIT press. 
Gan, W.B. (1991). On the deviation from PPP: the case of the ringgit effective exchange rate. Applied Economics, 23, 1461-1471.

Giovanneti. (1992). A survey of recent empirical tests of the Purchasing Power Parity hypothesis, Bank of Nazionale-del-Lavoro. Quarterly Review, March 81-101.

Glen, J. (1992). Real exchange rate in the short, medium, and long run. Journal of International Economics, 33, 147-166.

Hooper, P. \& Morton, J. (1982). Fluctuations in the dollar: A model of nominal and real exchange rate determination. Journal of Money Finance, 1(1), 39-56.

Johansen, S. (1988). Statistical analysis of cointegration vectors. Journal of Economic Dynamics and Control, 12, 231-254

Johansen, S. Juselius, K. (1990). Maximum likelihood estimation and inference on cointegration with application to the demand of money. Oxford Bulletin of Economics and Statistics, 52(3), 169-209.

Kim, Y. (1990). Purchasing Power Parity in the long run: A cointegration approach. Journal of Money, Credit, and Banking, 22, 491-503.

Krugman, P. (1990). Equilibrium exchange rate in international monetary policy coordination and exchange rate fluctuations in: William H. Branson, Jacob A. Frankel, Morris Goldstein Eds., Chicago: University of Chicago Press, 159-87.

MacKinnon, J.G. (1991). Critical values of cointegration tests. In R.F. engle and C.J. granger edits,. long run economic relation- ships: reading in cointegration, chapter (13), Oxford University Press, \& N.Y.

McNown, R. \& Wallace, M. (1989). National price levels, Purchasing Power Parity, and cointegration: A test of four high inflation economics. Journal of International Money \& Finance, 8, 553-545.

Meese, R. \& Rogoff, K. (1988). Was it real? The exchange rate-interest differential relation over the modern floating-rate period. Journal of Finance, 43, 933-948.

Melvin, M. (1997). International money and finance. $\left(5^{\text {th }} \mathrm{ed}\right)$. New York: Addison- Wesley.

Officer, L.H. (1978). The relationship between absolute and relative Purchasing Power Parity. The Review of Economics and Statistics, 60, 562-68.

Pippenger, M. (1993). Cointegration tests of Purchasing Power Parity: The case of the swiss exchange rate. Journal of International Money and Finance, 12, 46-61.

Rogof, K. (1996). The Purchasing Power Parity puzzle. Journal of Economic Literature, 34, 647-668.

Samuelson, P. (1964). Theoretical note on trade problems. Review of Economics and Statistics, 145-54.

Su Zhou, (1997). Purchasing Power Parity in highinflation countries: A cointegration analysis of integrated variables with trend breaks. Southern Economic Journal, 64(2), 450-467.

Taylor, M. (1988). An empirical examination of long-run Purchasing Power Parity using cointegration techniques. Applied Economics, 20, 1369-1381. 


\title{
NOTES FOR CONTRIBUTORS
}

\begin{abstract}
Manuscripts
Manuscripts should be written as accurately as possible and should be typed in double-spacing on one side of an A4 paper with margins at least $25 \mathrm{~mm}$. Each manuscripts should not exceed 25 pages. Manuscripts will be reviewed by a panel of referees. Comments will be made available to the contributors without disclosing the referees' names. Paper already accepted for any publication should not be submitted.The first page of your paper should contain the title, name(s), affiliation(s), address(es), telephone number(s), fax number(s) and email address(es).
\end{abstract}

\begin{abstract}
The abstract should be brief, self-contained, explicit and should not exceed 200 words. Local contributors are required to submit two (2) abstracts, one in Malay and the other in English.

\section{References}

References should be carefully checked. The references are to be cited in the text in the author-date format-APA style (5th Edition), for example : Anderson, Koonce \& Marchant, 1991; Gordon, 1999. A reference list, only of work cited, should be provided at the end of the text arranged in alphabetical order. Examples of the format for books and journals are follows:
\end{abstract}

Arnheim, R. (1971). Art and visual perception. Berkeley: University of California Press.

Festinger, L., Riecken, H. \& Scshachter, S. (1956). When prophecy fails. Minneapolis: University of Minnesota Press.

Roeder, K., Howdeshell, J., Fulton, L., Lochhead, M., Craig, K., Peterson, R., et. al. (1976). Nerve cells and insect behavior. Cambridge, MA: Harvard University Press.

Passons, W. (1976). Predictive validities of the ACT, SAT, and high school grades for the first semester GPA and freshman courses. Educational and Psychological Measurement, 271143 1144.

Sawyer, J. (1966). Measurement and prediction, clinical and statistical. Psychological Bulletin, 66 (3), 178-200

\begin{abstract}
Abbreviations
Full journal title should be used, for the first citation in any article. Accepted abbreviations or acronyms may be used for subsequent citations.
\end{abstract}

\section{Tables}

Tables should be numbered consecutively in the text in Arabic numerals.

\section{Illustrations}

Illustrations must be in a camera-ready form. Captions should be typed double-spaced in sequence, on a separate sheet of paper. Photographs, if any, should be large, clear, glossy prints, showing high-contrast. Each should be identified on the back, complete with the author's name and the number of the illustrations.

\section{Contributors}

Contributors must provide their full names, academic qualifications and addresses. A contributor will receive a complimentary copy of the issues in which his/her article appears and 10 off-prints.

\section{Submission of Manuscript}

Manuscript and enquiries should be directed to : Chief Editor, Malaysian Management Journal, Jabatan Penerbitan dan Teknologi Media, Universiti Utara Malaysia, 06010 UUM SINTOK, Kedah, Malaysia. 


\title{
Call for Papers
}

\section{MALAYSIAN MANAGEMENT JOURNAL (MMJ) UNIVERSITI UTARA MALAYSIA}

\section{Dear Prof./Sir/Madam/Miss}

The secretariat of Malaysian Management Journal (MMJ), Universiti Utara Malaysia would like to invite you and your friends to submit a paper to be considered for publication in our Malaysian Management Journal.

Malaysian Management Journal (MMJ) is a refereed journal published by Universiti Utara Malaysia in June and December of each year. Its main objective is to provide a channel for the publications of articles based on empirical research, original thoughts, comparative study and commentaries in management, economics, information technology, accounting and other related fields.

This journal would benefit not only academicians, but also laymen and practitioners.

\section{Submissions}

Manuscripts should be written as accurately as possible and should be double spaced, with wide margins, and printed on one side of the paper only. All pages should be numbered consequently. Tables, figures and footnotes should be numbered cansecutively in the text in Arabic numerals. Two copies of the paper should be submitted together. Manuscripts will be reviewed by a panel of referees. Notification of the acceptance will be emailed or posted to the corresponding author. Paper already accepted for any journal publication should NOT be submitted.

The first page of your paper should contain the title, name(s), affiliation(s), address(es), telephone number(s), fax number(s) and email address(es).

\section{Abstract}

The abstract should be briefed, self-contained, explicit and not more than 200 words. Local contributors are required to submit two (2) abstracts, one in Malay and the other in English.

\section{References}

All papers for this journal are to be submitted following the style of the American Psychological Association (APA) reference citations.

\section{Publication}

The contributor or the main contributors (if more than one author) will receive a complimentary copy of the issue in which his/her article appears and 10 off prints. The copyright of the published article would automatically be transfered to the publisher to ensure the widest possible dissemination of information.

Kindly submit your papers to:

\author{
Chief Editor / Managing Editor \\ Malaysian Management Journal \\ Jabatan Penerbitan dan Teknologi Media \\ Universiti Utara Malaysia \\ 06010 UUM Sintok \\ Kedah Darul Aman. \\ Email: zamimah@uum.edu.my \\ arpizah@uum.edu.my
}

Tel: 04/9284156 Fax: 04/9284142 